\title{
Legal Construction of Post-Mining Reclamation in Indonesia
}

\author{
Haris Retno Susmiyati ${ }^{1 *}$ \\ ${ }^{1}$ Law Faculty of Mulawarman University in East Kalimantan Indonesia \\ *Corresponding author. Email: harisretno@fh.unmul.ac.id
}

\begin{abstract}
The coal minings in Indonesia are recorded that there were 9.721 Mining Business Permits. The majority is mining with an open-pit mining system. It brings consequences to the emergence of mining pits in many places. These coal pits (void) become an issue for the people who live in the mining area. In East Kalimantan, since the 2010-2018 year, 28 people drowned in coal pits that were not reclaimed; most are children. The location of the coal pits spread across four districts and cities in East Kalimantan. Therefore the existence of the coal pits, which are not reclaimed, becoming a threat to the community. Based on those facts, then what becomes the legal questions in this study first: how is the construction for post-mining reclamation in the laws of Indonesia. The second question is the legal flaw in post-mining regulations in national regulations and local regulations in East Kalimantan. The method in this study is Normative legal research or also known as doctrinal legal research. Based on the study result, legal construction in post-mining reclamation regulations shows that post-mining reclamation is an obligation of every mining business permit holder. It is stipulated in Law Number 4 the Year 2009 concerning mineral and coal mining, Government Regulations Number 78 the Year 2010 about Post-Mining Reclamation, and Minister of Energy and Mineral Resources, Regulations Number 7 the Year 2014 about Implementation of Reclamation and Post-Mining in Mineral and Coal Mining Business Activities. At the local level of East Kalimantan Province through Regional Regulations Number 8 the Year 2013 about Post-mining Reclamation. However, that regulation substance has several weaknesses that cause mining pits' reclamation obligations are easily ignored. It sides to mining business importance more than society's safety who live in a mining area.
\end{abstract}

Keywords: Mining, Legal Construction, Void, Coal Pit, Post-mining Reclamation

\section{INTRODUCTION}

Mining exploitation history in Indonesia started in the Dutch colonialism era. The first regulations on the mining sector are made through Indische Mijwet 1899 Independent. It is issued Regulations Number 11 the Year 1967 about General Mining. Now Regulations Number 4 the Year 2009 about Mineral and Coal Mining is valid. The total mining permit in Indonesia, which is recorded, is 9721. Complete more than 3000 permissions are in Kalimantan Island. Mining majority is done by open-pit mining.

Open-pit mining is technically divided into four kinds, as follows: (1) Open Pit Mining; (2) Quarry; (3)
Strip Mine; (4) Alluvial Mining. ${ }^{1}$ That open-pit mining method starts with trees cutting which are on the surface of the soil and it continues with area stripping, soil and rock digging until reach the mining materials that are saved in bowel of the earth. It brings consequence to create pits in various places. Mining policy in Indonesia, submit the effort to overcome pits through reclamation mechanism.

Reclamation obligation is managed in mining regulations because mining activity can be claimed that almost all of it causes environmental damage. Therefore it needs responsibility for the company to reclaim the environment, which is in mining activity experienced

\footnotetext{
N. Sudrajat, Teori dan Praktik Pertambangan Indonesia. Pustaka Yustitia, Jakarta, 2013, pp. 137138.
} 
damage. ${ }^{2}$ Reclamation obligation is managed in mining regulations because, in mining activity, it can be claimed that almost all of it causes environmental damage; therefore, it needs responsibility for the company to reclaim the environment which is in mining activity experienced damage.

Giant size pits, and generally, it is full of rainwater and ex-mining water. Pits existence becomes a concern because it has a significant number. After all, the mining company will generally leave 2-3 ex-mining pits. Although based on law regulations, in the mining plan company supposes to do reclamation on e-mining pits. But all mining companies leave holes in their reclamation technically; they arrange pits and leave exmining pits without ex-mining pits reclamation.

Post-mining Reclamation is an obligation for every mining business permit holder as it is managed in Regulations Number. 4 the Year 2009 about Mineral and Coal Mining, Government Regulations Number 78 the Year 2010 about Post-Mining Reclamation, and Ministry of Energy and Mineral Resources Number 7 the Year 2014 about Reclamation Implementation and Post-Mining on Mineral and Coal Mining Business Activity. At the local level of East Kalimantan Province through Regional Regulations Number 8 the Year 2013 about post-mining reclamation.

Fact about the existence of ex-mining pits which is left, it becomes issues for society who live in a mining area. In East Kalimantan since 2010-2018, 29 people died in ex-mining pits, which is not reclaimed; the majority are children. Drowned location is spread across four regions and cities area in East Kalimantan. Therefore ex-mining pit which is not reclaimed becomes a threat for society.

Based on those facts, then that becomes the legal questions in this study: (1) how is the construction for post-mining reclamation in Indonesia's laws, (2) how is the legal flaw in post-mining regulations in national regulations and local regulations in East Kalimantan.

\section{RESEARCH METHOD}

The method in this study is normative legal research or also known as doctrinal legal research.

\section{DISCUSSION}

\subsection{Legal Construction of Post-Mining Reclamation in Indonesia}

According to Young, reclamation comes from the word "to reclaim"; it means "to bring back to proper

\footnotetext{
2 T. Haryati, Era Baru Hukum Pertambangan di Bawah Rezim UU Number 4 Tahun 2009, Yayasan Pustaka Obor Indonesia, Jakarta, 2015, p. 254.
}

state"; it is an effort to make condition becomes better for cultivation or make something good becomes better, along with it does not contain recovery implication to original condition. Still, it prioritizes the function and soil utilization principle. According to the different opinion that Hoskin delivers, mining reclamation activity aims to reach stability, safety for human and animal, negate risk, and improve economic value from the last soil reclamation. ${ }^{3}$

Kempton and Atkins mentioned the opinion above as the conventional purpose of mining reclamation. Nowadays, mining reclamation is mining sustainable mining reclamation, which means there is the purpose of keeping the biodiversity of flora and fauna, protecting human health, returning carrying capacity and environment capacity like the original, and strengthening society's social and cultural aspects. ${ }^{4}$

Reclamation based on Regulations Number 4 the Year 2009 about Mineral and Coal Article 1 Point 26, reclamation is done along with mining business stage to arrange, recover, and fix the environment and ecosystem qualities to function back as its function. Every mining company must have Reclamation Plan, according to the provision in Article 99 Point (1) about Mineral and Coal Regulations, as follows: Every Mining Business Permit Holder (MBP) and Special Mining Business Permit (SMBP) must give a reclamation plan ad post-mining plan when they submit MBP on Production Operation or SMBP on Production Operation.

Article 96 (c) Mineral and Coal Mining Regulations, mining business permit holder must do "management and supervision of the mining environment, including reclamation and post-mining". Article 99 (2) Number 4 the Year 2009 manages that post-mining reclamation implementation is done according to the allocation. This provision opens an opportunity for ex-mining pits are not reclaimed, with the primary allocation of it does not oblige the reclamation. This construction is made by Mineral and Coal Directorate Regulations. Managed exmining pits by the government look like they give mining company profit.

\footnotetext{
A. Zulkifli, Pengelolaan Tambang Berkelanjutan. Graha Ilmu, Yogjakarta, 2014, p. 80.

${ }^{4}$ Kempton, Atkins, Delayed Environmental Impacts from Mining in Semi-Arid Climates, in: Fith International Conference on Acid Rock Drainage, Denver Colorado, Vol.II. May 21-24, in Arif Zulkifli, Pengelolaan Tambang Berkelanjutan, Graha Ilmu, Yogyakarta, 2014
} 
Table 1. Construction of Mining Reclamation Law Regulations in Indonesia

\begin{tabular}{|c|c|c|}
\hline Legal Substance & Legal Construction & Regulations \\
\hline \multirow[t]{2}{*}{ Characteristic } & Reclamation must be done by the & Article 96 (c) Regulations Number 4 Year 2009 \\
\hline & company & Regulations of Mineral and Coal Directorate \\
\hline Time of Reclamation & Reclamation is done in 30 days of & Article 20 of Government Regulations Number \\
\hline Implementation & calendar after there is no activity & 77 Year 2010 \\
\hline \multirow[t]{9}{*}{ Businessman Obligation } & To submit reclamation plan proposal & Article 99 (1) Regulations Number 4 Year 2009 \\
\hline & & Regulations of Mineral and Coal Directorate; \\
\hline & & Article 6 Government Regulations Number 78 \\
\hline & & Year 2010 \\
\hline & The amount of reclamation security & Article 6 Government Regulations Number 78 \\
\hline & proposal & Year 2010 \\
\hline & To provide Reclamation Security fund & Article 100 (2) Regulations of Mineral and \\
\hline & & Coal, Article 29 of Government Regulations \\
\hline & & Number 78 Year 2010 \\
\hline \multirow[t]{8}{*}{ Government Obligation } & To agree or reject Reclamation Plan & Article 13 of Government Regulations Number \\
\hline & which is proposed by company & 78 Year 2010 \\
\hline & To agree the amount of Reclamation & Article 13 of Government Regulations Number \\
\hline & Security Fund & 78 Year 2010 \\
\hline & Reclamation supervision & Article $22-23$ of Governement Regulations 78 \\
\hline & & Year 2010 \\
\hline & To choose third party to do & Article 33 of Government Regulations Year \\
\hline & reclamation if company does not do it & 2010 \\
\hline \multirow[t]{4}{*}{ Punishment } & There is no imprisonment, just & Article 151 of Regulations Number 4 Year \\
\hline & administrative punishment & 2009 of Mineral and Coal Directorate; Article \\
\hline & & 50-51 of Government Regulations 78 Year \\
\hline & & 2010 \\
\hline \multirow[t]{3}{*}{ Reclamation Form } & Not must to close the pits but they just & Article 99 (2) of Regulations Number 4 Year \\
\hline & need to show the post-mining & 2009; Regulations of Energy and Mineral \\
\hline & allocation & Resources Number 7 Year 2014 Article 12 \\
\hline
\end{tabular}

3.2. How is the Legal Flaw in the Regulations of Reclaiming the Post-Mining in the Regulations of National and Local Regulations in East Kalimantan

Particularly post-mining reclamation is managed in Government Regulations Number 78 the Year 2010 about Reclamation and Post-Mining. Article 2 of Government Regulation Number 78 the Year 2010 about Reclamation and Post-Mining state that a company who holds a Mining Business Permit must do reclamation. But unfortunately, this provision contains weakness, and if the mining company did not do their obligation, the punishment is very weak.
Article 50 mentions punishment that is applied toward BMP holder who breaks reclamation is just administrative punishment. Administrative punishment is meant in the form of a written warning, activity temporary termination and BMP revote. BMP revote discipline has just become a threat for mining company, which is still in operation but related to reclamation. It does not have meaning because reclamation can be done on mining that finishes operating or half-done. The company will certainly choose reclamation after all activities are completed. Therefore if a reclamation is not done and the government revote their BMP, then 
Table 2. Total of Children who Dead in Coal Mining Pit in East Kalimantan

\begin{tabular}{lcl}
\hline City/Region & Total victims who drowned in ex-mining pits & Process of Law \\
\hline Samarinda & 18 & Just 2 victims, process of law toward securit of \\
& & pits with 3 months imprisonment and fine IDR. \\
& & $1000,-$ \\
Kutai Kartanegara & 11 & No process of law \\
West Kutai & 1 & No process of law \\
Penajam Paser Utara & 1 & No process of law \\
\hline Total & 31 & No process of law \\
\hline
\end{tabular}

administrative punishment ${ }^{5}$ does not have meaning if the company already stops. This punishment cannot be applied effectively. This reclamation feels strange, and the government deliberately free the mining company from reclamation.

The scenario which is on Government Regulation Number 78 the Year 2010, in the end, mining reclamation will be burdened to mining reclamation security which the company transfers. Article 100 point (1) of Mining and Coal Directorate Regulations state that BMP and SBMP must provide reclamation security fund and post-mining security fund. Furthermore, based on Article 100 point (2) and (3) Minister, Governor, or Regent/Major, according to their authority can decide the third party to do reclamation and post-mining with security fund if BMP or SBMP does not do reclamation and post-mining according to plan which was agreed.

In fact that mining pits which are left without reclamation show that there is a problem to determine reclamation security fund. Reclamation security fund is not done transparently, as the result that there is no control from society. When children drowned case appears, it appears confession from the government that all this time reclamation fund determination is very low that it cannot suffice to reclaim mining pit by the third party.

According to Article 6 of Government Regulations, Provision asserts that BMP Exploration and SBMP exploration Holders who have done appropriateness

\footnotetext{
${ }^{5}$ Administrative sanctions are exceptions that can be imposed directly or forced by government institutions that try without waiting for a court order. In Indonesia it is assumed that the imposition of law requires changes that have been there before, such as permits issued by the government. Sanctions that occur in a person or several conditions that have been terms of the permit. (Muh Jufri Dewa, Sanksi Hukum Bagi Pelaku Pencemaran dan Perusakkan Lingkungan Hidup, Jurnal Sumber Daya Insani Universitas Muhammadiyah Kendari, Edisi Januari 2009, Nomor 15, h. 117).
}

study must submit reclamation plan agreement proposal and post-mining plan to Minister, Governor, or Regent/Major according to their authority. The reclamation plan and post-mining plan are offered simultaneously with BMP Production Operation and SBMP Production Operation proposals.

This article is profitable for businessman because BMP Production Operation still can be issued before the reclamation plan agreement exists. After all, the reclamation plan agreement limit is 30 days after BMP publish must decide, if the plan is not appropriate, then it will be returned to BMP holder, and BMP holder has 30 days to fix reclamation plan.

This reclamation provision shows that central and regional governments have the authority to agree or disagree with the reclamation plan that the company proposes; it includes the authority to determine the amount of reclamation security fund provided by the company. The agreement process of reclamation plan and the amount of reclamation fund is done unilaterally by the government, and there is no society participation space. Although, when the company starts to operate and cause mining pits, society must be susceptible to unsafe situations.

Government respond toward children who drowned in mining pits is shocking because this issue about children drowned in mining pits did not finish. Mining pits cannot be reclaimed; the central government issue the Ministry of Energy and Mineral Regulations Number 7 the Year 2014 about Reclamation and PostMining Implementation on Business of Mineral and Coal Mining. This Ministry Regulation precisely legalizes mining pits not to be reclaimed as its origin. It mentions in Article 12(4): Reclamation program in production operation stage can be implemented in revegetation and/or the other purpose. The other purpOse as it mentions in Article 12 (5) it can be in the form of (a) residential area, (b) tourism, (c) water source, (d) cultivation area.

Whereas the provision on Article 12(6): in mining activity technically left pits, then it must make the exmining pits utilization plan, as follows: (a) slope stabilization, (b) ex-mining Pits Security, (c) restoration 
and supervision of water quality along with ex-mining pits according to its allocation, (d) ex-mining pits preservation.

Based on that provisions, then ex-mining pits can be let open, and they do not reclaim, as long as there is its allocation formally. The existence of mining pits that are not reclaimed cause 30 victims drowned in that exmining pits. Besides that, as mentioned in this provision and in its implementation, its allocation just applied formally on the paper, whereas mining pits only left behind in the field. This option shows the government refers to the conventional reclamation concept, and it does not refer to the sustainable reclamation concept.

Reclamation management at the regional level can be seen as one example in East Kalimantan, which manage through the Regional Regulations of East Kalimantan Province Number 8 the Year 2013 about Reclamation and Post-mining Managements. There are several interesting issues in this Regional Regulations; first: the size of ecological unity becomes principle in Regional Regulations, as mentioned in Article 2, is based on unity principle of ecological protection in East Kalimantan Province to give protection toward environment and society importances. It becomes crucial to point to the sustainable development concept.

Secondly, the obligation of mining business permit holder to place reclamation security fund, according to Article 16 Point (3) in this Regional Regulations, the reclamation security fund placing must be announced in mass media. This provision is an effort of well information transparency. But this provision is not enough because the early provision process of the reclamation security fund amount is still done closely and does not open to the public.

Thirdly, the form of reclamation and post-mining supervision commission through a selection process consist of the academy, professional and the relevant state employee assigned, as managed in Article 20-22. Commission job is to do supervision as it is handled in Article 23, as follows: (a) the truth between reclamation plan document and reclamation implementation realization; (b) the truth between the document of postmining activity plan and completion of post-mining implementation; (c) accept complaining report based on negative impact which is caused by mineral and coal mining activity; (d) to continue supervision result to an authorized agency about supervision result which is indicated there is law violation; (e) to deliver supervision activity result to Governor periodically at least one time in (six) months.

Fourth, there is the authority in Reclamation Supervision Commission that supervision result which is done in the next can be done: (a) if it is found administration violation element then it is given to agency which according to regulations, (b) if there is a criminal act then it is reported to Indonesian National Police investigator, (c) beside that reclamation commission can recommend to the agency in charge in the living environment to accuse to permit holder who does pollution and/or destroy the live environment. But in its implementation, the post-mining reclamation commission cannot do its function well. Follow-up of supervision result is not delivered openly to the public. It can be said that the reclamation supervision commission to reduce reclamation issues in East Kalimantan is not significant.

\section{CONCLUSION}

(1) Reclamation Law Construction of ex-mining pits oblige the company to do reclamation also place reclamation security fund sufficiently to restore exmining soil

(2) There is a weakness in mining reclamation law regulation is triggered by law product which the central government makes from Mining and Coal Directorate Regulations or Government Regulation Number 78 the Year 2010 about Reclamation and Post-mining along with Ministry of Energy and Mineral Resources Number 7 the Year 2014 about Reclamation and Coal Implementation which are very weak to force mining company to do reclamation, especially the punishment is ineffective because it is just administrative. Even in law provision, it gives an opportunity for mining company not to do reclamation. Law provision places reclamation security as the end of the way if the company does not do it. Still, the fund amount is not done transparently because reclamation security fund provision often does not suffice reclamation need.

\section{SUGGESTION}

Based on that law facts, there must be revision toward law about mining reclamation to force mining company to do reclamation. If there is no changing toward law, it is proved that the government deliberately let ex-mining pits without reclamation.

\section{REFERENCES}

[1] N. Sudrajat, Teori dan Praktik Pertambangan Indonesia, Pustaka Yustitia, Jakarta, 2013.

[2] T. Haryati, Era Baru Hukum Pertambangan di Bawah Rezim UU Nomor 4 Tahun 2009, Yayasan Pustaka Obor Indonesia, Jakarta, 2015.

[3] A. Zulkifli, Pengelolaan Tambang Berkelanjutan, Graha Ilmu, Yogyakarta, 2014.

[4] Regulations Number 4 the Year 2009 about Mineral and Coal Mining. 
[5] Government Regulations 78 the Year 2010 about Reclamation and Post Mining.

[6] Ministry of Energy and Mineral Resources Number 7 the Year 2014 about Reclamation and Post Mining Implementation .

[7] Regional Regulations of East Kalimantan Province Number 8 the Year 2013 about Reclamation and Post-mining Managements. 